\title{
Николаева С.И. \\ Формирование универсальных учебных действий на уроках истории в рамках ФГОС
}

doi 10.18411/gq-31-03-2021-37

МБОУ «Средняя школа №16», (Россия, Новый Уренгой)

idsp sciencerussia-31-03-2021-37

\section{Аннотация}

Работа посвящена вопросу формирования универсальных учебных действий на уроках истории. Представлены способы формирования познавательных умений школьников, таких, как сравнение, анализ объектов с целью выделения существенных признаков, работа с графической информацией, исторической картой, письменным историческим источником.

На протяжении всей отечественной истории образование подвергалось различным реформам. Продолжается этот процесс и сейчас, ведь современная жизнь предъявляет человеку жесткие требования - наличие высокого качества образования, коммуникабельности, креативности, умения ориентироваться в большом потоке информации и, конечно, конкурентоспособность. Потребность современного общества такова, что, вступая во взрослую жизнь, выпускники будут постоянно сталкиваться с проблемой выбора, будут искать ответы на жизненные вопросы, принимать решения. Задача учителя - помочь ребятам найти себя в будущем, стать самостоятельными, творческими и уверенными в себе людьми.

В рамках реформы образования на смену традиционному преподаванию приходит системно-деятельностное, составляющее основу ФГОС и предъявляющее новые требования как к учителю, так и к ученику. Новой задачей образования становится обеспечение развития универсальных учебных действий (УУД). Через формирование УУД происходит развитие личности, создается возможность самостоятельно овладевать знаниями и умениями и делать это успешно.

Модернизация образования затронула и историческое образование. Сегодня недостаточно дать детям знания об исторической картине мира, важно выработать у них интерес к предмету, развить историческое мышление как основу миропознания, научить работать с разными источниками информации, а также критически подходить к действительности, формировать активную гражданскую позицию.

Как в текущих реалиях наиболее грамотно выстроить процесс обучения?

В Программе развития УУД выделены четыре блока: личностный, регулятивный, познавательный и коммуникативный. На уроках истории при изучении одних тем может уделяться большое внимание формированию одних видов УУД, в других - на формирование иных УУД. Но в целом, содержание учебного курса истории должно быть выстроено так, чтобы одним из планируемых результатов изучения различных тем стало бы формирование всех видов универсальных учебных действий.

Остановлюсь на формировании познавательных УУД. К ним относятся: смысловое чтение и работа с текстом, умение строить логические рассуждения и формулировать выводы, проводить классификацию объектов по выбранным критериям, выдвигать гипотезу и обосновывать её, устанавливать причинноследственные связи, анализировать объекты с целью выделения существенных признаков, переводить информацию из одной знаковой системы в другую и др.

В формировании умений школьников на уроках истории есть свои особенности. Во-первых, преобладают сложные по структуре умения; во-вторых, практические 
умения связаны, в основном, с работой источника; в-третьих, построение учебного материала подчинено логике раскрытия знаний о прошлом; в-четвертых, необходимость в использовании одного и того же познавательного умения возникает не последовательно из урока в урок, а может появляться через ряд уроков.

В ФГОС ООО определены требования к предметным результатам освоения учебного предмета «История», отражающим сформированность различных умений школьников. Основная задача учителя - посредством учебных заданий создать условия, инициирующие деятельность обучающихся. Разрабатывая план урока, необходимо выделить основные виды деятельности ученика (на уровне учебных действий), составить вопросы и задания на отработку необходимых умений. Приведу примеры формирования некоторых из них.

1. Умение сравнивать и выделять линии сравнения. Объектом сравнения могут быть: исторические события и явления, исторические эпохи, историческое время, отдельные личности. В ходе работы можно использовать наглядные средства, такие как карта, картина, схемы, диаграммы. Широко применяются исторические документы.

В процессе изучения темы «Дух предпринимательства преобразует экономику» в 7 классе в качестве задания предлагаю классу рассмотреть рисунки $(1,2)$ и сравнить ремесленную мастерскую и мануфактуру, сформулировать вопросы для сравнения, заполнить таблицу 1».

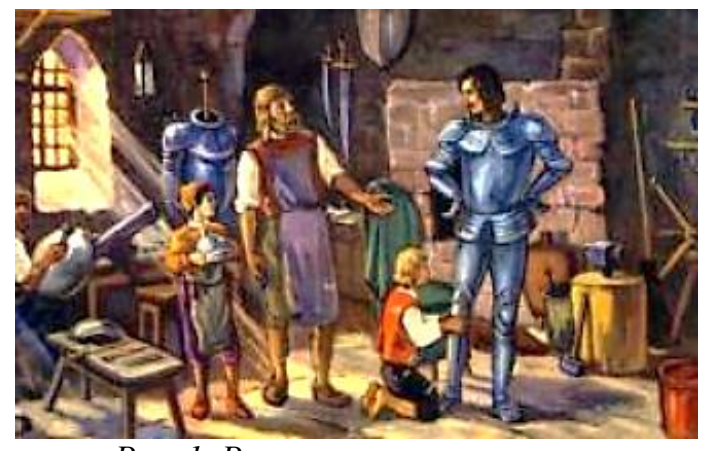

Рис. 1. Ремесленная мастерская

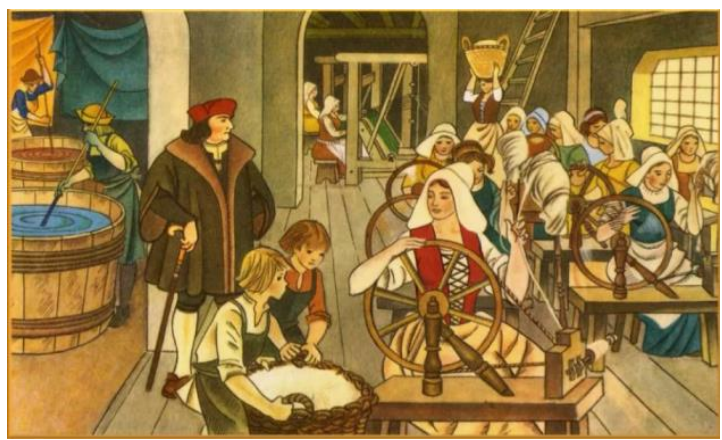

Pис. 2. Мануфактура

Таблица 1.

Ремесленная мастерская и мануфактура

\begin{tabular}{|l|l|l|}
\hline Вопросы для сравнения & Ремесленная мастерская & Мануфактура \\
\hline & & \\
\hline
\end{tabular}

Учащиеся могут выделить следующие сравнительные признаки: размеры предприятия, количество работников, использование труда (ручного или машинного), разделение и производительность труда.

Формирование приёма сравнения у учащихся на уроках способствует развитию у детей наблюдательности, вырабатывает умение мыслить, делать выводы, ведёт к сознательному усвоению материала и подготавливает к самостоятельному обобщению знаний.

2. Умение переводить информацию из одной знаковой системы в другую. С целью формирования данного умения пятиклассникам по теме «Рабство в Древнем Риме» можно предложить подписать диаграмму 1 в соответствии с фактами: «В Италии в эпоху завоеваний было 2-3 миллиона рабов и еще 4-5 миллионов свободных граждан (соотношение 1 к 2)».

Работа с диаграммой, схемой способствует развитию логического и аналитического мышления учащихся. 


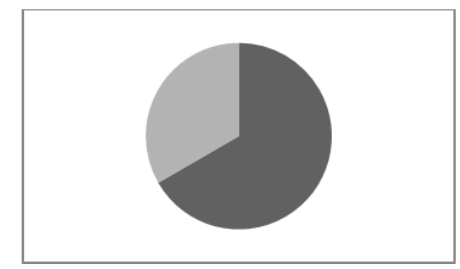

Диаграмма 1.

3. Умение читать и использовать для получения информации историческую карту. Одной из важных задач учителя истории является формирование картографической грамотности обучающихся. Учащимся могут быть предложены различные учебные задания на развитие следующих умений:

- поиск и анализ информации;

- систематизация исторического материала в виде составления таблицы;

- сравнение;

- историко-картографическое моделирование;

- $\quad$ работа с картой в составе комплекса источников. Например, прочитайте текст, соотнесите его содержание с картой, подготовьте рассказ.

Для отработки школьниками учебных действий, связанных с поиском и анализом картографической информации, учитель может придерживаться следующих этапов формирования данного умений:

1. Создание учителем мотивационной основы формирования выбранного умения.

2. Объяснение школьникам способа выполнения действий (введение памятки для учащихся).

3. Демонстрация учителем образца выполнения задания и выполнение ребятами задания для тренировки (выполняется под контролем учителя).

4. Выполнение учащимися действий с опорой на памятку при самоконтроле.

5. Применение классом умений в измененных условиях.

Приведу пример самостоятельного выполнения задания учащимися 5 класса. Учитель предлагает рассмотреть карту «Индия в древности», охарактеризовать географическое положение и природные условия с опорой на памятку.

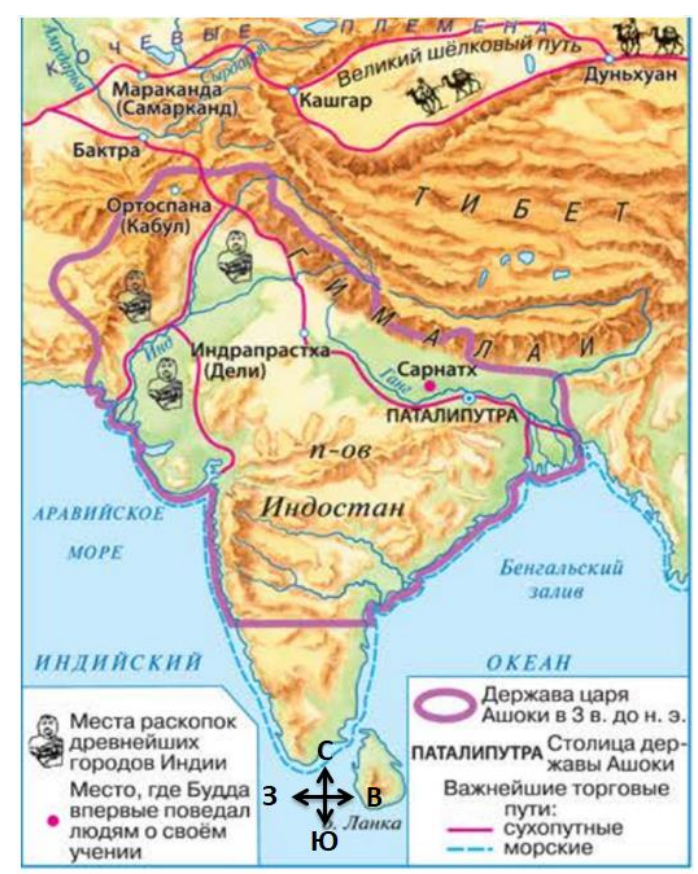

Карта. Индия в древности 
Памятка.

1. Прочитай название карты.

2. Изучи легенду карты (условные знаки, которые позволят прочитать информацию, изображенную на карте).

3. Чтение информации на карте начинай с самых крупных объектов и постепенно двигайся к более мелким, придерживайся принципа «часовой стрелки» (север-восток-юг-запад).

4. Найди и покажи на карте требуемые объекты, словесно опиши их (географическое положение страны, природные и социальные объекты, торговые пути, военные походы и т.д.).

Разнообразные задания по исторической карте позволяют сохранить интерес к работе с исторической картой, формируют картографические знания и умения учащихся, а в сочетании с другими видами информации развивают познавательный интерес к изучению предмета.

4. Умение работать с письменным историческим источником. Отработка данного умения может происходить на двух уровнях: репродуктивном (извлечение информации из текста) и преобразующем (анализ, сравнение, оценка источника).

Приведу задание преобразующего характера в 7 классе по теме «Московское государство во второй половине XV века». На уроке ребята знакомятся с различными историческими трудами, учатся давать оценку исторической личности.

Один из исследуемых текстов представлен отрывком из научно-популярной статьи Лаушкина А., Мельникова С., Володихина Д., «Рождение Московского государства. Иван III». М., 1995 г.

«Личность Ивана Великого была противоречива, как и время, в которое он жил. В нём уже не было пылкости и удали первых московских князей, но за его расчётливым прагматизмом ясно угадывалась высокая цель жизни. Он бывал грозен и часто внушал ужас окружающим, но никогда не проявлял бездумной жестокости и, как свидетельствовал один его современник, был «до людей ласков», не гневался на мудрое слово, сказанное ему в упрёк. Он никогда не торопился, но, поняв, что время действовать настало, действовал быстро и решительно. Мудрый и осмотрительный, Иван III умел ставить перед собой ясные цели и достигать их».

Вопросы к тексту:

1. Кто является автором документа?

2. О каком правителе идет речь в источнике?

3. В чем, по мнению авторов, проявилась противоречивость личности Ивана III?

4. За что упрекают государя авторы документа? Приведите цитату из текста. Согласны ли вы с ними?

5. Как относится к государю его современник?

6. Сформулируйте свое отношение к правлению Ивана III.

Использование исторических документов в обучении истории позволяет учителю развивать самостоятельность учащихся на уроке. Ученик сам учится получать необходимую информацию и анализировать ее. Выводы, полученные в результате работы с историческим источником, становятся более убедительными, содействуют конкретизации исторического материала, служат основой для развития познавательной активности школьников.

Таким образом, хорошо спланированная системная работа учителя по формированию УУД школьников приносит практическую пользу, а именно способствует качественному усвоению знаний, формирует активную гражданскую 
позицию, развивает мышление, учит работать с разными источниками информации и критически подходить к действительности.

$$
* * *
$$

1. Проект ФГОС ОOO URL: https://www.preobra.ru/fgosooo19 (дата обращения: 07.02.2021).

2. Кузин Д.В. Лазукова Н.Н. Учимся приобретать и осмыслять знания. Пособие для учителя и учащихся. СПб. Корона-Принт, 1998

\section{Серебрянцева О.Г. \\ Интерактивная технология как развивающий элемент обучения иностранному языку в вузе}

ГБОУ ВО Московский городской педагогический университет (Россия, Москва)

doi 10.18411/gq-31-03-2021-38

idsp sciencerussia-31-03-2021-38

\section{Аннотация}

Метод case-study или метод кейсов, который можно назвать развивающим методом и интерактивной кейс-технологией, становится все более актуальным в российской образовательной системе и начинает активно применяться преподавателями иностранного языка в нелингвистических вузах, что позволяет формировать и развивать профессиональные коммуникативные навыки. Интерактивная кейс-технология вовлекает студентов в активную классную, групповую и самостоятельную работу, позволяет формировать знания, умения и навыки на основе анализа и решения реальной или смоделированной проблемной ситуации, представленной в виде случая.

Ключевые слова: кейс-стади, интерактивная технология обучения, виды технологий, анализ ситуации, виды кейсов, принятие решения.

Метод case-study (кейс-стади - от англ. "case" - случай, "study" - изучать, исследовать) или метод кейсов в настоящее время продолжает набирать популярность и актуальность в нашей стране, как развивающий инструмент обучения, позволяющий применить теоретические знания к решению практических задач.

Кейс-технология - это интерактивная технология обучения, позволяющая формировать знания, умения и навыки на основе анализа и решения реальной или смоделированной проблемной ситуации, представленной в виде кейса (случая, ситуации), который требует вовлеченности обучающегося в классную и самостоятельную работу.

Развитие навыков профессиональной коммуникации на иностранном языке является целью обучения взаимодействию специалистов в профессиональной деятельности, которые должны повышать свою коммуникативную компетентность, знать формы и методы воздействия на оппонентов или собеседников, то есть совершенствовать культуру общения [2].

В нелингвистическом вузе профессионально-ориентированное общение на иностранном языке определяется как обмен профессионально-значимой информацией, обеспечивающий взаимопонимание между партнерами по общению, то есть представителями различных профессиональных сообществ [3].

Уделяя внимание навыкам коммуникации на профессиональную тему, преподаватель нелингвистического вуза, применяющий метод case-study, имеет дополнительную возможность развивать навыки общения будущих специалистов.

Данный метод способствует развитию у учащихся самостоятельного мышления с одной стороны, и умения выслушивать и учитывать альтернативную точку зрения с 